\title{
FUNCTIONAL RESIDUAL CAPACITY (FRC) AND COMPLIANCE IN ANAESTHETIZED PARALYSED CHILDREN PART II. CLINICAL RESULTS
}

\author{
T.L. DobBinson, M.B., CH.B., F.F.A.R.A.C.S., \\ H.I.A. NisBET, M.B., CH.B., F.F.A.R.C.S.(ENG.), F.R.C.P.(C), \\ D.A. Pelton, M.D., F.R.C.P.(C), And H. Levison, M.D. \\ With the technical assistance of $\mathrm{G}$. VoLGYFsI
}

\section{INTRODUCTION}

Anaesthesia and artificial ventilation may reduce the functional residual capacity (FRC) of the lungs, ${ }^{1-6}$ cause increased flow resistance in some areas of the lung ${ }^{7}$ and alter distribution of inspired gas. ${ }^{6.8}$

As lung volume decreases, the small airways diminish in size and at a certain lung volume ("closing volume," CV) these airways start to close. A decrease in FRC resulting from both anaesthesia and the assumption of the supine position during operation may cause hypoxaemia if the FRC becomes lower than the closing volume."

It is known that the generally observed fall in FRC following induction of anaesthesia is related to the ratio of weight to height if the subjects are breathing spontaneously, ${ }^{3}$ that body configuration plays an important part in determining the effect of the supine position upon pulmonary mechanics, ${ }^{10}$ that static elastic recoil of the lung at a given lung volume varies with age, ${ }^{11}$ and that in young anaesthetized animals assuming the upright posture FRC increases less than it does in older animals. ${ }^{12}$

To study the effects of anaesthesia and artificial ventilation upon FRC specifically in children, we used the technique of FRC measurement described in a companion paper. ${ }^{13}$

Both lung compliance $\left(\mathrm{C}_{\mathrm{L}}\right)$ and $\mathrm{FRC}$ are proportionally reduced when conscious subjects change from the standing to the supine position, and so specific compliance $\left(\mathrm{C}_{\mathrm{LS}}\right)$ is unaltered by the change in posture. ${ }^{14}$ To discover whether $\mathrm{C}_{\mathrm{L} . \mathrm{s}}$ was within normal limits in anaesthetized children we measured $\mathrm{C}_{\mathrm{L}}$ and calculated $\mathrm{C}_{\mathrm{L} . \mathrm{s}}$ in some of our subjects.

From the Departments of Anaesthesia and Paediatrics, The Research Institute, The Hospital for Sick Children, Toronto, Canada, and the Department of Anaesthesia, The University of Toronto, Toronto, Canada.

Address for reprints. Dr. H.I.A. Nisbet, Department of Anaesthesia, The Hospital for Sick Children, 555 University Avenue, Toronto 101, Ontario, Canada.

This work was supported by a grant from the Physicians' Services Incorporated Foundation. Some of the apparatus used in this investigation was purchased with the aid of a grant from the Canadian Red Cross Youth (Ontario).

Paper read by T.L. Dobbinson at the Royal Australasian College of Surgeons 45th General Scientific Meeting, Hobart, Tasmania, 1972; and in part by Dr. H.I.A. Nisbet at the 5th World Congress of Anaesthesiologists, Kyoto, Japan, September 1972. 


\section{Methods}

\section{Clinical Material}

Nineteen children who were candidates for orthopaedic operations on the limbs and who had no evidence of cardiac or respiratory disease were studied. They were regarded as normal for the purpose of this investigation.

Fourteen children who were due to have surgical correction of congenital cardiac anomalies formed a second study group.

\section{Measurements}

In all the patients FRC was measured before operation in the supine position and without pre-medication. The values for the normal children were plotted against height to provide a standard graph for normal awake children in the supine position. In 14 of these children and in 11 of the children with congenital cardiac anomalies, FRC was measured again after the induction of anaesthesia.

In eight patients of the normal group repeated measurements of FRC were made early in the operation in order to test the reproducibility of the values measured by the helium dilution technique.

Lung compliance was not measured before induction of anaesthesia, but for nine patients in the normal group and nine patients in the group with congenital cardiac anomalies we were able to determine both FRC and $C_{L}$ early and late in the operative period and to calculate early and late $C_{\mathrm{I} . s}$ values by dividing $\mathrm{C}_{\mathrm{L}}$ by $\mathrm{FRC}$.

\section{Procedure and Method of Measuring FRC During Anaesthesia}

Anaesthesia was induced by thiopentone, $5 \mathrm{mg} / \mathrm{Kg}$, with atropine, $0.02 \mathrm{mg} / \mathrm{Kg}$, and after paralysis with succinylcholine chloride the child was intubated with a cuffed tracheal tube. A balloon was then passed into the oesophagus and, when spontaneous ventilation returned, it was positioned so that it recorded the maximum negative pressure change during inspiration. Dynamic lung compliance was measured by the method of Mead and Whittenberger ${ }^{15}$ using the oesophageal balloon, a pneumotachograph inserted in the airway, a differential pressure transducer and an amplifier recorder system incorporating a storage oscilloscope and respiratory module.

When the balloon was in the optimal position the child was again paralyzed with d-tubocurarine $(0.5 \mathrm{mg} / \mathrm{Kg})$ and ventilation was continued with a mixture of 0.5 to 1 per cent of methoxyflurane in either pure oxygen or 50 per cent oxygen and nitrogen. The piston ventilator ${ }^{13}$ was set to deliver a tidal volume of $10 \mathrm{ml} / \mathrm{Kg}$ and in cases where arterial blood was available the respiratory rate was varied to maintain an arterial carbon-dioxide tension of $35 \mathrm{~mm}$ of mercury.

During anaesthesia FRC was determined by the technique we developed for accurately measuring known volumes in a dummy lung. ${ }^{13}$

Once priming of the circuit was complete, spirometer temperature and the patient's oesophageal or nasopharyngeal temperature were recorded and the kymograph motor was turned on with the pen in recording position in preparation for measurement of FRC.

The ventilator was stopped at the end of an inspiratory stroke and the fresh gas and expiratory ports of the ventilator circuit were clamped at the end of expiration. 
TABLE I

\begin{tabular}{|c|c|}
\hline $\begin{array}{r}\text { PAIRED Mr } \\
\text { FRC IN } 1 \\
\text { Patie } \\
\text { OP }\end{array}$ & $\begin{array}{l}\text { NTS OF } \\
\text { RMAL } \\
\text { TG }\end{array}$ \\
\hline & \\
\hline $\begin{array}{l}(1) \\
478 \\
686 \\
684 \\
393 \\
399 \\
559 \\
462 \\
469\end{array}$ & $\begin{array}{c}(2) \\
483 \\
706 \\
677 \\
380 \\
426 \\
550 \\
443 \\
474\end{array}$ \\
\hline $\begin{array}{rl}\overline{\mathbf{x}} & 516 \\
\mathrm{SD} & 116.1\end{array}$ & $\begin{array}{l}517 \\
118.3\end{array}$ \\
\hline
\end{tabular}

$\overline{\mathbf{x}}=$ mean value.

$\mathrm{SD}=$ standard deviation.

$\mathrm{ns}=$ not significant.

A tidal volume was drawn from the spirometer into the ventilator, the obstructing clamps were removed from the circuit, and the ventilator was set in motion again.

Oxygen inflow was adjusted to maintain the circuit at the "switch in" volume and the oesophageal pressure trace was observed for changes in pressure. Rarely, a deviation of $1 \mathrm{~cm} \mathrm{H} \mathrm{H}_{2} \mathrm{O}$ from the "switch in" pressure occurred and was corrected for by adjusting the weight on the spirometer bell.

Usually one or two minutes elapsed before the helium concentration was stable. When equilibration was not complete within 3 to 4 minutes, it was assumed that there was a leak in the circuit.

After equilibration the ventilator was stopped, oxygen inflow was simultaneously shut off and the helium dilution measuring circuit was closed to allow gas to be collected for determination of oxygen and carbon-dioxide concentrations. The inspiratory and expiratory clamps were then removed from the ventilator circuit and mechanical ventilation was resumed.

In calculating the FRC we disregarded the small decrease in anatomical deadspace which results from tracheal intubation. ${ }^{16}$

\section{Results}

Paired measurements of FRC in eight normal children during operation showed no significant difference between successive determinations using the modified helium dilution technique (Table I).

Figure 1 shows the correlation between FRC and height in 14 normal children when awake and when anaesthetized. The slope of the line relating FRC to height was increased under anaesthesia. In small or young children the line lay outside the 95 per cent confidence limits (Figures 1 and 2).

In normal children under 11 years of age, FRC decreased under anaesthesia by an average of 44 per cent in contrast to an average decrease of only 27 per cent in 


\section{FRC SUPINE}

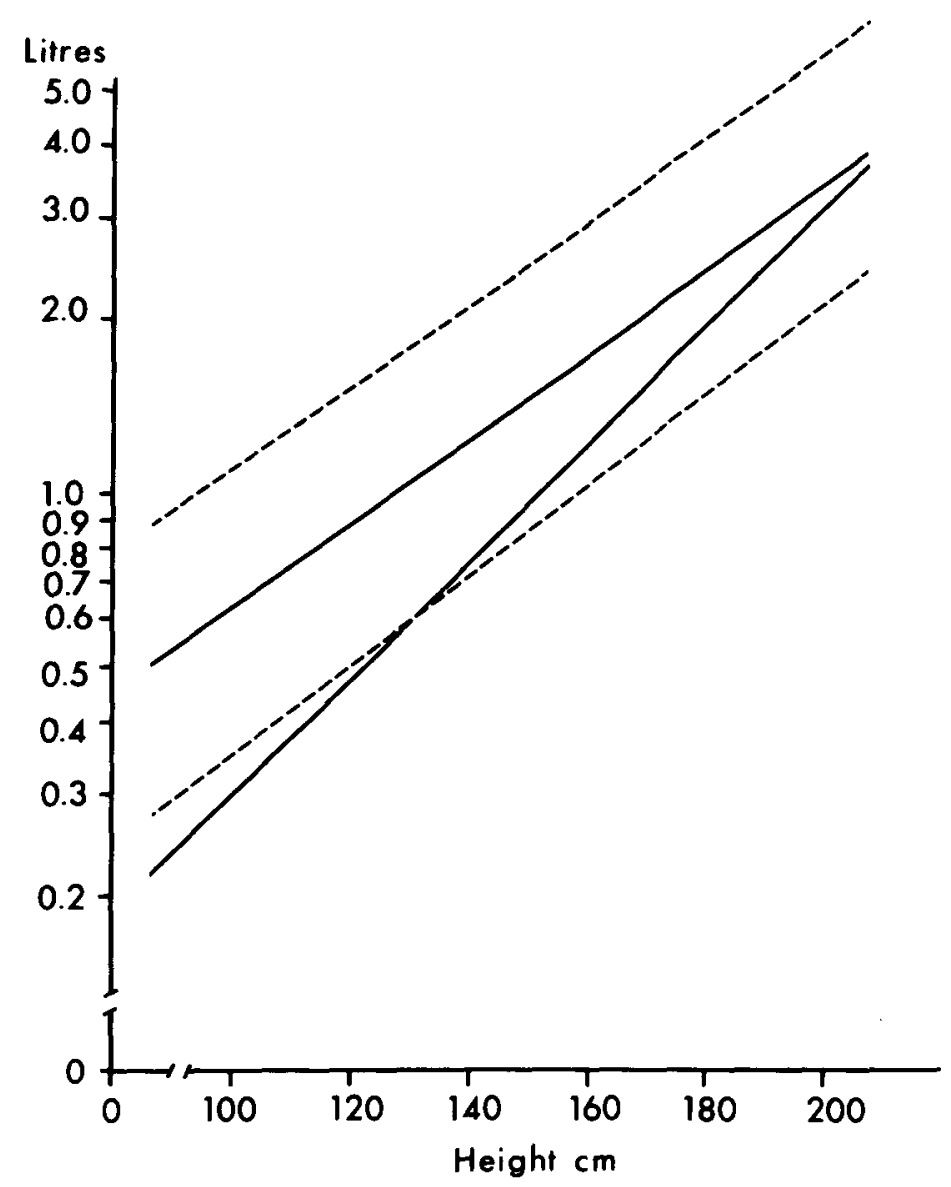

FIGURE 1. Relationship of FRC to height in normal children, awake and during anaesthesia with artificial ventilation. The upper solid line represents the mean values for the supine awake children. The lower solid line represents the mean values for these children when anaesthetized and ventilated. The broken lines represent the 95 per cent confidence limits.

older children (Table II). Overall, the mean fall in FRC was 35 per cent for the normal children but only 20 per cent for the children with congenital cardiac anomalies (Tables II and III).

\section{FRC During Operation}

In the normal group FRC did not change significantly from beginning to end of operation (Table IV). In contrast, however, FRC continued to decrease during the operation in the children with congenital cardiac anomalies (Table V), so that at the end of the operation the mean fall from post-induction values was 24 per cent.

The use of 100 per cent oxygen did not appear to influence the magnitude of the early fall in FRC either in normal children or in those with congenital cardiac anomalies (Figure 3). 


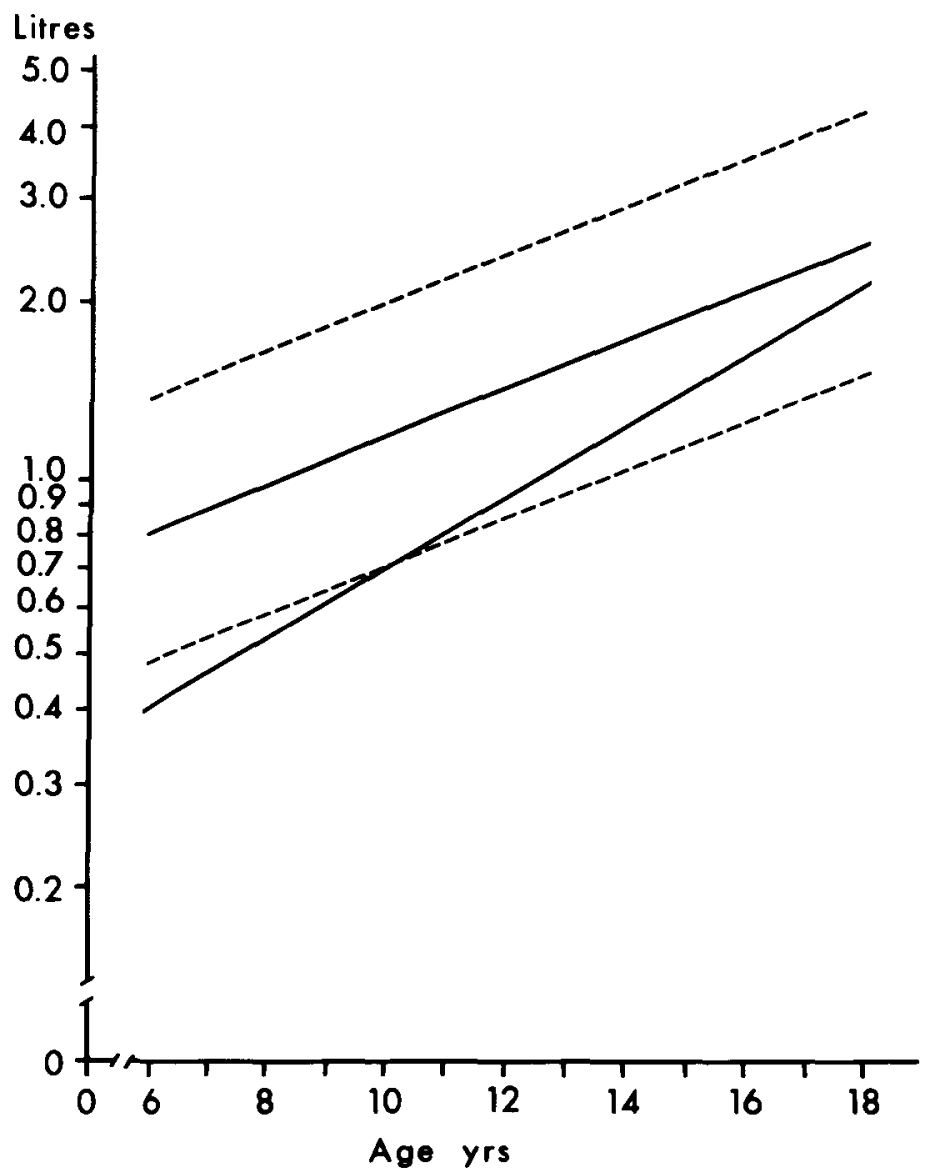

Figure 2. Relationship of FRC to age in normal children, awake and during anaesthesia with artificial ventilation. The upper solid line represents the mean values for the supine awake children. The lower solid line represents the mean values for these children when anaesthetized and ventilated. The broken lines represent the 95 per cent confidence limits.

\section{Lung Compliance During Operation}

In both groups of children $\mathrm{C}_{\mathrm{L}}$ fell significantly during operation (Tables IV and V).

\section{Specific Lung Compliance}

In nine normal children, during early anaesthesia the mean $\mathrm{C}_{\mathrm{L} . \mathrm{s}}$ was $0.068 \mathrm{ml} /$ $\mathrm{cmH}_{2} \mathrm{O} / \mathrm{mI}$; at the end of operation it had significantly decreased (Table VI).

In nine children undergoing cardiac surgery, $\mathrm{C}_{\mathrm{L} . \mathrm{s}}$ was lower than in normal children both at the beginning and at the end of operation, but the decrease in $\mathrm{C}_{\mathrm{Ls}}$ during operation was insignificant (Table VI). 
TABLE II

FRC (Supine) Values in 14 Normal Children, Awake and Anaesthetized

\begin{tabular}{|c|c|c|c|c|c|}
\hline \multirow[b]{2}{*}{ Age, years } & \multicolumn{2}{|c|}{$\mathrm{FRC}, \mathrm{ml}$} & \multicolumn{3}{|c|}{ Difference in FRC } \\
\hline & Awake & Anaesthetized & $\mathrm{ml}$ & & $\%$ \\
\hline $\begin{array}{c}13 \\
14 \\
11 \frac{1}{2} \\
18 \\
12 \\
15 \\
7 \\
14 \\
10 \\
7 \\
10 \\
8 \frac{1}{2} \\
13 \\
6\end{array}$ & $\begin{array}{l}1200 \\
1700 \\
1860 \\
2980 \\
1230 \\
1820 \\
1040 \\
2620 \\
1230 \\
0960 \\
1070 \\
0760 \\
1100 \\
0940\end{array}$ & $\begin{array}{l}0950 \\
0920 \\
0800 \\
2370 \\
0950 \\
1210 \\
0450 \\
1800 \\
0590 \\
0500 \\
0830 \\
0550 \\
1200 \\
0400\end{array}$ & $\begin{array}{l}-0250 \\
-0780 \\
-1060 \\
-0610 \\
-0280 \\
-0610 \\
-0590 \\
-0820 \\
-0640 \\
-0460 \\
-0240 \\
-0210 \\
+0100 \\
-0540\end{array}$ & & $\begin{array}{l}-21 \\
-45 \\
-57 \\
-20 \\
-22 \\
-34 \\
-58 \\
-31 \\
-52 \\
-48 \\
-22 \\
-28 \\
+10 \\
-57\end{array}$ \\
\hline & & & & $\begin{array}{r}\mathbf{n} \\
\overline{\mathrm{x}} \\
\mathrm{p}\end{array}$ & $\begin{array}{r}14 \\
-35 \\
19.4 \\
<0.001\end{array}$ \\
\hline
\end{tabular}

TABLE III

FrC (Supine) Values in 11 Children with Cardiac Anomalies, Awake and Anaesthetized

\begin{tabular}{|c|c|c|c|c|c|}
\hline \multirow[b]{2}{*}{ Age, years } & \multicolumn{2}{|c|}{$\mathrm{FRC}, \mathrm{ml}$} & \multicolumn{3}{|c|}{ Difference in FRC } \\
\hline & Awake & Anaesthetized & $\mathrm{ml}$ & & $\%$ \\
\hline 9 & 0980 & 0830 & -150 & & -15 \\
\hline 11 & 1530 & 1360 & -170 & & -11 \\
\hline 7 & 1080 & 0870 & -210 & & -19 \\
\hline 8 & 0720 & 0650 & -070 & & -10 \\
\hline 7 & 0790 & 0700 & -090 & & -11 \\
\hline 9 & 1010 & 0640 & -370 & & -37 \\
\hline 8 & 0520 & 0550 & +030 & & +06 \\
\hline 16 & 1740 & 0970 & -770 & & -44 \\
\hline 8 & 1040 & 0730 & -310 & & -30 \\
\hline \multirow{5}{*}{$10 \frac{1}{2}$} & 0930 & 0630 & -300 & & -32 \\
\hline & 0780 & 0700 & -080 & & -11 \\
\hline & & & & $\frac{n}{x}$ & \\
\hline & & & & $\mathrm{SD}$ & $\begin{array}{l}-20 \\
14.7\end{array}$ \\
\hline & & & & p & $<0.005$ \\
\hline
\end{tabular}


TABLE IV

Lung Compliance $\left(C_{L}\right)$ and FRC During Operation; 11 Normal Children

\begin{tabular}{|c|c|c|c|c|c|c|c|c|}
\hline \multirow[b]{2}{*}{ Age, years } & \multicolumn{2}{|c|}{$\mathrm{C}_{\mathrm{L}}, \mathrm{ml} / \mathrm{cm} \mathrm{H}_{2} \mathrm{O}$} & \multicolumn{2}{|c|}{ Difference in $\mathbf{C}_{\mathbf{L}}$} & \multicolumn{2}{|c|}{$\mathrm{FRC}, \mathrm{ml}$} & \multicolumn{2}{|c|}{$\begin{array}{l}\text { Difference } \\
\text { in FRC }\end{array}$} \\
\hline & Early & Late & $\mathrm{ml} / \mathrm{cm} \mathrm{H}_{2} \mathrm{O}$ & $\%$ & Early & Late & $\mathrm{ml}$ & $\%$ \\
\hline 9 & 40 & 36 & -4 & -10 & 530 & 550 & +20 & +4 \\
\hline 13 & 71 & 67 & -4 & -6 & 950 & 930 & -20 & -2 \\
\hline 14 & 65 & 50 & $-1 \overline{5}$ & -23 & 920 & 900 & -20 & $-\overline{2}$ \\
\hline $11 \frac{1}{2}$ & 42 & 42 & 0 & 0 & 800 & 730 & -70 & $-\overline{9}$ \\
\hline 18 & 150 & 150 & 0 & 0 & 2370 & 2380 & +10 & 0 \\
\hline 12 & 63 & 55 & -8 & -13 & 950 & 950 & 0 & 0 \\
\hline 15 & 70 & 63 & -7 & -10 & 1210 & 1160 & -50 & -4 \\
\hline 7 & 29 & 23 & -1 & -4 & - & - & - & - \\
\hline 18 & 150 & 150 & 0 & 0 & 1800 & 2000 & +200 & +11 \\
\hline 10 & 60 & 55 & -5 & -8 & - & $\overline{410}$ & -20 & $\overline{-5}$ \\
\hline 5 & 30 & 25 & -5 & -17 & 430 & 410 & -20 & -5 \\
\hline$\frac{\mathrm{n}}{\mathrm{x}}$ & 11 & 11 & 11 & 11 & 9 & $\begin{array}{r}9 \\
9\end{array}$ & $\begin{array}{r}9 \\
+5\end{array}$ & $\begin{array}{l}9 \\
9\end{array}$ \\
\hline$\stackrel{\bar{x}}{S D}$ & $\begin{array}{l}70 \\
42\end{array}$ & $\begin{array}{r}65 \\
44\end{array}$ & $\begin{array}{l}-5 \\
.5\end{array}$ & -8 & 1107 & 111.2 & +5 & $\begin{array}{l}\mathbf{0} \\
6\end{array}$ \\
\hline p & & & $<0.005$ & & 618 & 657 & ns & \\
\hline
\end{tabular}

$\mathrm{n}=$ number of cases.

$\overline{\mathbf{x}}=$ mean value.

$\mathrm{SD}=$ standard deviation.

$\mathrm{p}=$ probability.

ns $=$ not significant.

TABLE V

Lung Compliance $\left(C_{L}\right)$ and FRC During Operation: 12 Children with Cardiac Anomalies

\begin{tabular}{|c|c|c|c|c|c|c|c|c|}
\hline \multirow[b]{2}{*}{ Age, years } & \multicolumn{2}{|c|}{$\mathrm{C}_{\mathrm{L}}, \mathrm{ml} / \mathrm{cm} \mathrm{H} \mathrm{H}_{2} \mathrm{O}$} & \multicolumn{2}{|c|}{ Difference in $C_{L}$} & \multicolumn{2}{|c|}{$\mathrm{FRC}, \mathrm{ml}$} & \multicolumn{2}{|c|}{$\begin{array}{l}\text { Difference } \\
\text { in FRC }\end{array}$} \\
\hline & Early & Late & $\mathrm{ml} / \mathrm{cm} \mathrm{H}_{2} \mathrm{O}$ & $\%$ & Early & Late & $\mathrm{ml}$ & $\%$ \\
\hline 9 & 27 & 25 & -2 & -7 & 830 & 580 & -240 & -30 \\
\hline 11 & 60 & 32 & $-2 \overline{8}$ & -47 & 1360 & 930 & -430 & -32 \\
\hline 7 & 35 & 31 & -4 & -11 & 870 & 600 & -170 & -20 \\
\hline 8 & 24 & 16 & $-\tilde{8}$ & -33 & 650 & 400 & -150 & -23 \\
\hline 7 & 40 & 22 & -18 & -45 & 700 & 610 & -90 & -13 \\
\hline $5 \frac{1}{2}$ & 44 & 27 & -17 & -39 & 480 & 400 & -80 & -17 \\
\hline 8 & 31 & 18 & -13 & -42 & 550 & 360 & -190 & -35 \\
\hline 6 & - & - & - & - & 420 & 280 & -140 & -33 \\
\hline 13 & 80 & 50 & -30 & -38 & 1130 & 890 & -240 & -21 \\
\hline 16 & - & - & & - & 970 & 840 & -130 & -13 \\
\hline 8 & 33 & 30 & -3 & -10 & 730 & 640 & -90 & -12 \\
\hline 9 & - & - & - & - & 630 & 410 & -220 & -35 \\
\hline $\mathrm{n}$ & 9 & 9 & 9 & 9 & 12 & 12 & 12 & 12 \\
\hline $\bar{x}$ & 42 & 29 & -13 & -27 & 777 & 578 & -181 & -24 \\
\hline SD & 18 & 9 & 11 & 19 & 274 & 218 & 97 & 9 \\
\hline $\mathrm{p}$ & & & 0.005 & & & & $<0.001$ & \\
\hline
\end{tabular}

$\mathrm{n}=$ number of cases.

$\overline{\mathrm{x}}=$ mean values.

$\mathrm{SD}=$ standard deviation.

$\mathrm{p}=$ probability.

ns $=$ not significant. 


\section{FRC SUPINE}

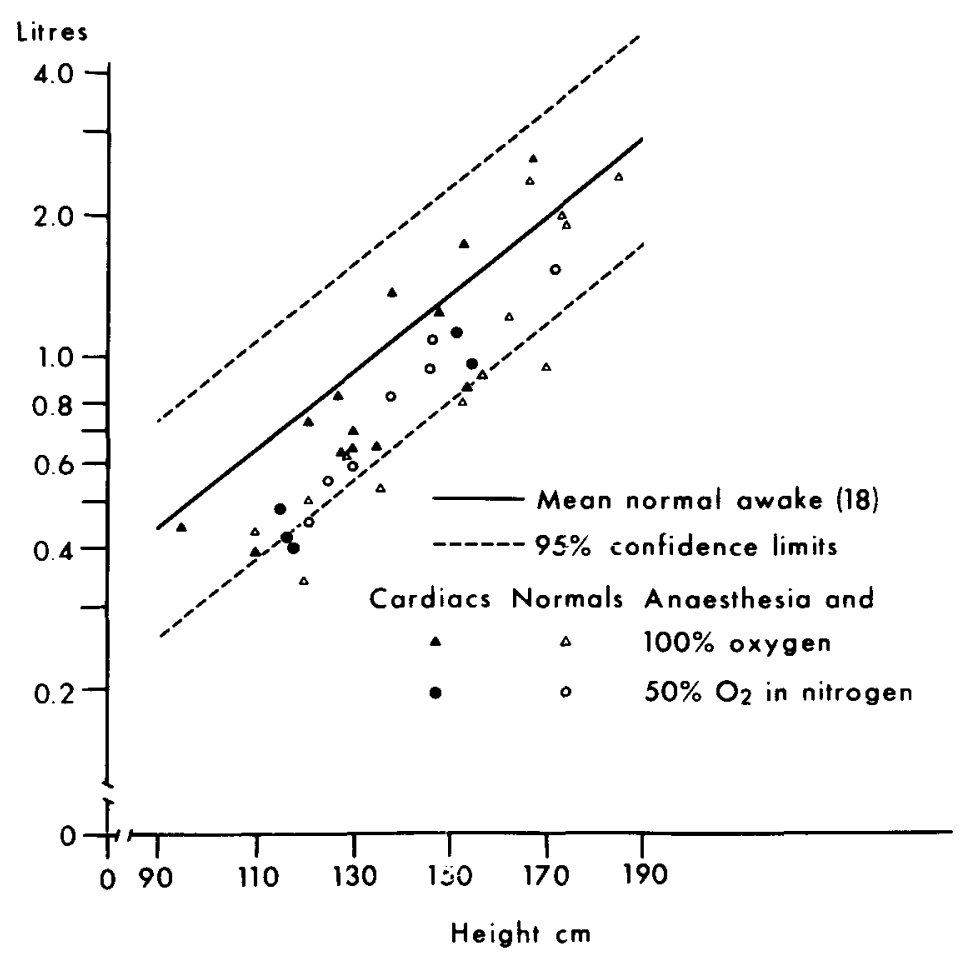

FigURE 3. FRC during anaesthesia using 50 per cent and 100 per cent oxygen in children with and without congenital cardiac anomalies: comparison with normal awake values. ${ }^{18}$ The broken lines represent the $\mathbf{9 5}$ per cent confidence limits.

\section{Discussion}

The decrease of 35 per cent in FRC values after induction in the normal children is similar in magnitude to that measured by Don $e t a l .^{3}$ in spontaneously breathing adult subjects when anaesthetized. In their studies the fall in FRC correlated well with weight/height ratio. Such a correlation is not evident in this study of children under artificial ventilation. Here the decrease in FRC is greater than that reported for anaesthetized and artificially ventilated adults, in whom the fall in FRC ranges from 0 to 18 per cent. ${ }^{1,5,6}$

The increased slope of the FRC-height line during anaesthesia and artificial ventilation and the larger decrease in FRC for children under 11 years may be connected with age-related structural differences in the lungs, such as the relative absence of collateral channels of ventilation in younger children. Differences in body configuration may also increase the forces tending to collapse the lungs of young children.

If FRC decreases or $\mathrm{CV}$ increases so that $\mathrm{FRC} / \mathrm{CV}<1$, airway closure may occur during tidal breathing and the patient may become hypoxaemic. ${ }^{9}$ The 


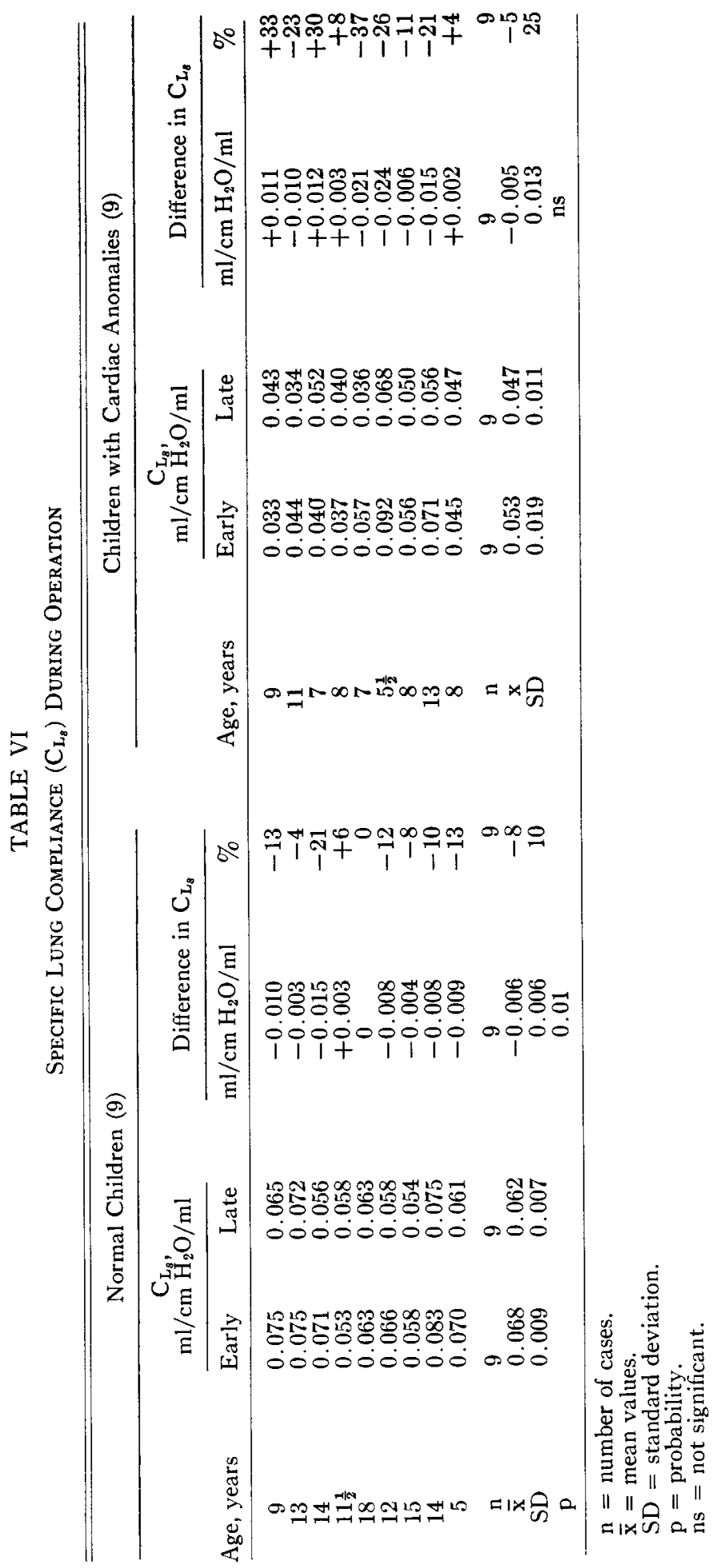


relatively large falls in FRC measured in the younger children during this investigation suggest considerable danger of hypoxaemia in these patients.

Déry et al. ${ }^{4}$ demonstrated a fall in FRC in adults inhaling 100 per cent oxygen but not in those inhaling 50 per cent oxygen/nitrogen. Don et al. ${ }^{3}$ found that the decreased FRC under anaesthesia was not related to the inspired oxygen concentration and our results support this conclusion.

\section{Changes in FRC During Operation}

The decrease in FRC during operation in both groups of children was ultimately of similar magnitude - the difference seems to be in rate rather than in degree. The slower fall in FRC in children with cardiac lesions may be related to the increased peripheral airway resistance observed in some cardiac patients, but the difference in the length and nature of operations makes interpretation of changes difficult.

\section{Relationship of FRC and Compliance During Operation}

Changes in compliance indicate the degree of atelectasis during operation. ${ }^{17}$

The mean value of $\mathrm{C}_{\mathrm{L} s}$ obtained in normal children during early anaesthesia $(0.068 \mathrm{ml} / \mathrm{cmH} . \mathrm{O} / \mathrm{ml})$ is only slightly higher than the value of 0.05 to $0.06 \mathrm{ml} /$ $\mathrm{cm} \mathrm{H}_{2} \mathrm{O} / \mathrm{ml}_{\text {quoted by Comroe }}{ }^{19}$ for conscious adults, and the small but significant fall in $\mathrm{C}_{\mathrm{L}}$ in these children was not accompanied by a significant fall in FRC. The $\mathrm{C}_{\mathrm{Ls}}$ value at the end of the operation $\left(0.062 \mathrm{ml} / \mathrm{cmH}_{2} \mathrm{O} / \mathrm{ml}\right)$ is still close to Comroe's figure, suggesting that in the ventilated areas of the lung $C_{\mathrm{I} . \mathrm{r}}$ remains within normal limits.

It is unlikely that the changes in lung compliance were due to changes in the positions of the oesophageal balloon, as this was checked at the end of operation and significant changes were also recorded in total thoracic compliance.

Lim et al. ${ }^{14}$ found that both $\mathrm{C}_{\mathrm{L}}$ and $\mathrm{FRC}$ were proportionally reduced in adults on changing from the standing to the supine position and therefore $\mathrm{C}_{\mathrm{L} . *}$ remained the same in the two body positions. From our data it would appear that anaesthesia and artificial ventilation in the supine position are associated with a fall in $\mathrm{C}_{\mathrm{I} . \mathrm{s}}$, but not below the normal range.

Although $\mathrm{C}_{\mathrm{L}, \mathrm{s}}$ remains close to normal values in ventilated children with normal cardiac and respiratory function, the large fall in FRC may be associated with airway closure, an increase in trapped gas volume and impaired oxygenation.

For the children undergoing cardiac surgery the value of $\mathrm{C}_{\mathrm{L} . \mathrm{s}}$ obtained carly in the operation was lower $\left(0.053 \mathrm{ml} / \mathrm{cmH}_{2} \mathrm{O} / \mathrm{ml}\right)$ than for the normal children. This may in part be due to the differences in the nature of the operations, but reports of low static lung compliance in children with congenital cardiac anomalics ${ }^{18}$ make it probable that these children are at a disadvantage from the start.

From our study we concluded that both normal children and those with congenital cardiac anomalies would benefit from measures designed to maintain FRC during anaesthesia and artificial ventilation. 


\section{SUMMARY}

Because anaesthesia and artificial ventilation may be associated with reduction of FRC leading to hypoxaemia, we measured changes in FRC and compliance during anaesthesia ( 0.5 per cent to 1 per cent methoxyflurane) and artificial ventilation in children with normal respiratory function undergoing operation on the limbs and in children with congenital cardiac anomalies undergoing surgical correction. After induction of anaesthesia in the normal children FRC fell in 35 per cent and remained at a fairly steady level throughout the operation. The lesser post-induction fall of 20 per cent observed in the children undergoing cardiac surgery was followed by a continued decrease in FRC during the surgical operation. At the end of operation the reduction in FRC was of similar magnitude in each group of children.

The post-induction fall in FRC was greater than that reported for anaesthetized adults during artificial ventilation, and was inversely proportional to the size of the child.

$\mathrm{C}_{\mathrm{Ls}}$ in the normal children was slightly greater at the beginning of operation than at the end, the final value being close to the reported normal figure for conscious subjects.

In the children with congenital cardiac anomalies $\mathrm{C}_{\mathrm{I} . \mathrm{s}}$ was less than in the normal children both at the beginning of operation and at the end.

Both normal children and those with congenital cardiac anomalies would benefit from measures designed to maintain FRC during anaesthesia and artificial ventilation.

\section{RÉSUMÉ}

Du fait que l'anesthésie et la ventilation artificielle peuvent participer à la réduction de C.R.F. et conduire à l'hypoxémie, nous avons mesuré les changements de la C.R.F. et de la compliance durant l'anesthésie ( 0.5 à 1 pour cent de méthoxyflurane) et la fonction respiratoire était normale et qui subissaient une opération sur les membres et nous avons fait les mêmes mesures chez des enfants porteurs d’anomalies cardiaques congénitales soumis à la chirurgie pour corrrection. Après induction de l'anesthésie chez les enfants normaux, la C.R.F. a diminué chez 35 pour cent des cas et elle est demeurée à un niveau assez uniforme durant toute l'opération. La plus faible diminution de 20 pour cent après l'induction, observée chez les enfants soumis à la chirurgie cardiaque, a été suivie par une diminution continue de C.R.F. durant la chirurgie. A la fin de l'opération, la diminution de C.R.F. était de la même importance dans chaque groupe d'enfants.

La diminution de C.R.F. post-induction était plus considérable que celle rapportée chez les adultes anesthésiés durant la ventilation artificielle et elle était inversement proportionnelle au poids de l'enfant.

$\mathrm{C}_{\mathrm{L} s}$, chez les enfants normaux, était légèrement plus grande au début de lopération qu'à la fin; la valeur finale était très voisine des chiffres normaux rapportés chez les sujets conscients.

Chez les enfants porteurs d'anomalies cardiaques congénitales, $\mathrm{C}_{\mathrm{L}, \mathrm{s}}$ était inférieure à celle des enfants normaux aussi bien au début qu’à la fin de l'opération.

Les deux groupes : les enfants normaux aussi bien que les porteurs d'anomalies 
cardiaques congénitales bénéficieraient des mesures destinées à maintenir la C.R.F. durant l'anesthésie et la ventilation artificielle.

\section{ACKNOWLEDGMENTS}

We wish to thank the following at the Hospital for Sick Children, Toronto: the Divisions of Orthopaedic Surgery and Cardiovascular Surgery for their co-operation, Mrs. Indira Maharaj for her technical assistance, and the Departments of Medical Publications and Visual Education for their help in preparing this paper.

\section{REFERENCES}

1. Hickey, R.F., Visick, W., Fairuey, H.B., \& Fourcade, H.E. Functional residual capacity and pulmonary oxygenation during controlled and spontaneous ventilation. Abstracts of Scientific Papers, 1971 American Society of Anesthesiologists Annual Meeting, Atlanta, Georgia, p. 79.

2. Colgan, F.J. \& Whang, T.B. A method for measuring the functional residual capacity and dynamic lung compliance during oxygen and halothane inhalation. Anesthesiology 28: 559 ( 1967 ).

3. Don, H.F., Wahba, M., Cuadrado, L., \& Kelkar, K. The effects of anaesthesia and 100 per cent oxygen on the functional residual capacity of the lungs. Anesthesiology 32: $521(1970)$.

4. Déry, R., Pelletier, J., Jacques, A., Clavet, M., \& Houde, J. Alveolar collapse induced by denitrogenation. Can. Anaesth. Soc. J. 12: 531 (1965).

5. LAws, A.K. Effects of induction of anaesthesia and muscle paralysis on functional residual capacity of the lungs. Can. Anaesth. Soc. J. 15: 325 (1968).

6. Marsh, H.M., Rehder, K., Sessler, A.D., \& Fowler, W.S. Effect of posture, muscle paralysis and mechanical ventilation on ventilation-perfusion relation in anesthetized man. Fed. Proc. 30: 217 (1971) (Abstract).

7. Ting, E.Y., Hong, S.K., \& RAHN, H. Lung volumes, lung compliance and airway resistance during negative-pressure breathing. J. Appl. Physiol. 15: 554 (1960).

8. Kaneko, K., Milic-Emili, J., Dolovich, M.B., Dawson, A., \& Bates, D.V. Regional distribution of ventilation and perfusion as a function of body position. J. Appl. Physiol. 21: 767 (1966).

9. Don, H.F., Craig, D.B., Wahba, W.M., \& Couture, J.G. The measurement of gas trapped in the lungs at functional residual capacity and the effects of posture. Anesthesiology 35: 582 (1971).

10. Gold, M.I. \& Helrich, M. Pulmonary compliance during anaesthesia. Anesthesiology 26: 281 (1965).

11. Zapletal, A., Misur, M., \& Samanex, M. Static recoil pressure of the lungs in children. Bull. Physiopathol. Resp. 7: 139 (1971).

12. Davidson, J.T., Wasserman, K., \& Lillington, G.A. Lung compliance of the rabbit and posturally induced changes in functional residual capacity. Anesthesiology 27: 817 (1966).

13. Dobbinson, T.L., Nisbet, H.I.A., \& Pelton, D.A. Functional residual capacity (FRC) and compliance in anaesthetized paralyzed children. Part 1: Methods. In press.

14. LIM, T.P.K. \& LUFT, E.C. Alterations in lung compliance and functional residual capacity with posture. J. Appl. Physiol. 14: 164 (1959).

15. MeAd, J. \& Whittenberger, J.L. Physical properties of human lungs measured during spontaneous respiration. J. Appl. Physiol. 5: 779 (1953).

16. Marshall, B.E. Physiological shunting and deadspace during spontaneous respiration with halothane and oxygen anaesthesia and the influence of intubation on the physiological deadspace. Brit. J. Anaesthesia 38: 912 (1966).

17. Finley, T.N. Anaesthesia and atelectasis. Editorial. Anesthesiol. 29: 863 (1968).

18. Dobbinson, T.L., Gray, I.G., Nisbet, H.I.A., Pelton, D.A., \& Levison, H. Thoracic compliance and lung volumes in children with heart disease. In press.

19. Comroe, J.H., Jr., Forster, R.E., it, Dubois, A.B., Briscoe, W.A., \& Carlsen, E. The lung. Clinical physiology and pulmonary function tests, 2nd Edition, Chicago, Year Book Medical Publishers, Inc., 1962, p. 173. 